\title{
Performance Evaluation of a Field-Scale Anaerobic Baffled Reactor as an Economic and Sustainable Solution for Domestic Wastewater Treatment
}

\author{
Yasmin Saif ${ }^{1}$, Mahwish Ali ${ }^{2}$, Ian M. Jones ${ }^{3}{ }^{-1}$ and Safia Ahmed ${ }^{1, *}$ \\ 1 Department of Microbiology, Faculty of Biological Sciences, Quaid-i-Azam \\ University, Islamabad 45320, Pakistan; yasmin.saif@bs.qau.edu.pk \\ 2 Department of Biological Sciences, Faculty of Multidiciplinary Studies, National University of Medical \\ Sciences, Rawalpindi 46000, Pakistan; mahwish.ali@numspak.edu.pk \\ 3 School of Biological Sciences, University of Reading, Reading RG6 6UB, UK; i.m.jones@reading.ac.uk \\ * Correspondence: sahmed@qau.edu.pk; Tel.: +92-51 9064-3009
}

Citation: Saif, Y.; Ali, M.; Jones, I.M.; Ahmed, S. Performance Evaluation of a Field-Scale Anaerobic Baffled Reactor as an Economic and Sustainable Solution for Domestic Wastewater Treatment. Sustainability 2021, 13, 10461. https://doi.org/ $10.3390 /$ su131810461

Academic Editor: Alessio Siciliano

Received: 12 August 2021

Accepted: 15 September 2021

Published: 20 September 2021

Publisher's Note: MDPI stays neutral with regard to jurisdictional claims in published maps and institutional affiliations.

Copyright: (C) 2021 by the authors Licensee MDPI, Basel, Switzerland. This article is an open access article distributed under the terms and conditions of the Creative Commons Attribution (CC BY) license (https:// creativecommons.org/licenses/by/ $4.0 /)$.

\begin{abstract}
The present study explored the efficiency of a four-chambered anaerobic baffled reactor (ABR) as a cost-effective and sustainable method of organic pollutant and pathogen removal from domestic wastewater, under a range of environmental conditions. An ABR with a circular additional filter at the outlet pipe was constructed to treat wastewater from a residential colony of 108 households with an average inflow of $110 \mathrm{~m}^{3} /$ day and a nominal hydraulic retention time (HRT) of $20 \mathrm{~h}$. Analysis of the chemical oxygen demand (COD), total nitrogen, sulfate and phosphate load, and total coliform removal for 2 years of operation, 2015 and 2017, showed a COD of $46 \%$, sulfate load of $28 \%$, phosphate load of $51 \%$ and total nitrogen of $28 \%$ for 2015 , compared to a COD of $48 \%$, sulfate load of $44 \%$, phosphate load of $58 \%$ and total nitrogen of $31 \%$ for 2017 . The lack of a significant effect of sludge removal suggested a stable process. The overall efficiency of the ABR increased in the summer, including for pathogen removal, which was significantly higher during the summer months of both years. Overall, the ABR was found to be able to consistently treat primary wastewater, although tertiary effluent treatment was still required before water reuse or final discharge.
\end{abstract}

Keywords: anaerobic baffled reactor; COD; temperature; residential wastewater; pathogen removal

\section{Introduction}

Global challenges, including urbanization, climate change, aging societies, and environmental and water crises, are increasingly becoming critical in terms of their impact on the quality of life [1,2]. Although wastewater reuse is merited for its ability to lessen the water demand from primary sources, wastewater has been used improperly for many years for agriculture purposes and can present a risk to public health and the environment [3].

The wastewater production in Pakistan is 962,335 million gallons per day and less than $5 \%$ of it is treated at the primary level. In fact, only $1 \%$ of wastewater gets satisfactory treatment, due to a lack of proper plant maintenance and the fact that sustainable wastewater treatment processes that are suitable for rural Pakistan are scarce. Ultimately, most wastewater produced goes into larger water bodies without receiving essential treatment [4]. At the same time, the Pakistan Council of Research in Water Resources has opined that Pakistan may run dry by 2025 unless wastewater reuse improves. Accordingly, there is an urgent need to develop and apply economical and sustainable wastewater treatment solutions in Pakistan [5].

Here, an anaerobic baffled reactor is examined as a sustainable solution with the goal of treating domestic wastewater with a low energy requirement and an acceptable level of environmental clean-up. The potential for ABR use has been shown to be valuable when compared to other technologies, due to its resilience to hydraulic shock loads, caused by flow variation because of the number of inhabitants and dwellings connected to the sewer 
system, and the climatic conditions [6]. Notably, compartmentalized ABR designs lead to the establishment of suitable microorganisms for anaerobic digestion, the separation of liquid and solid phases, and system stability $[7,8]$. Moreover, the separation of the acidogenic and methanogenic phases accelerates the hydrolysis of nitrogenous compounds and carbohydrates, and the operating costs are low when compared to other wastewater treatment technologies, making its use cost effective and long lasting [9-11].

ABR passage also kills pathogenic bacteria while retaining useful levels of phosphorus and nitrogen in the sludge, both of which mean that treated water may be used for improved crop yields [12]. Thus, ABR use is an appropriate option for developing countries [13], where it acts as a replacement for septic tank use for onsite domestic wastewater treatment. Septic tanks pose higher potential risks because of their inability to absorb hydraulic shocks, their inferior treatment of sludge, and resultant underground pollution of surface water and the water table [14-16].

Despite their benefits, field-scale performance data following ABR implementation are scarce or affected by area-specific treatment-limiting factors, although several laboratorybased studies have been reported [6,17].

Pakistan experiences four significant seasons throughout the year, with temperatures varying from 0 to $40^{\circ} \mathrm{C}$, and has a land mass that varies in altitude by $8611 \mathrm{~m}(28,251 \mathrm{ft})$. In this study, the use of a field-scale four-chambered ABR in on-site conditions, without the use of an external energy source, as a treatment for a decentralized wastewater treatment system (DEWATS), was examined for its efficiency and sustainability over a two-year period.

\section{Materials and Methods}

\subsection{Unit Design and Experimental Setup}

The volume of the ABR and its design were based on the number of households to be treated at Quaid-i-Azam University (QAU) residential colony and the flow of wastewater, which was $\sim 110 \mathrm{~m}^{3} /$ day, calculated by the float method of Grand and Dawson [18]. The site of the ABR was chosen following survey of three different existing drain locations and the calculated footprint requirement. The ABR was constructed of brick masonry with a plaster render with dimensions $12.8 \mathrm{~m} \times 4.572 \mathrm{~m} \times 2.75 \mathrm{~m}(\mathrm{~L} \times \mathrm{W} \times \mathrm{H})$ and included four digester chambers and six baffled walls, three vertical and three hanging, each of $0.23 \mathrm{~m}$ thickness. In the last chamber, a columnar filter $1 \mathrm{~m}$ diameter and $1.84 \mathrm{~m}$ high filled with broken brick masonry of $\sim 2-5 \mathrm{~cm}$ diameter was constructed. Holes of 5-10 cm diameter were left in the outer wall and the filtrate drained into a perforated PVC pipe running through it, which was connected to the outlet. The vertical baffles contained eight horizontal $0.30 \mathrm{~m} \times 0.15 \mathrm{~m}(\mathrm{~L} \times \mathrm{H})$ openings at the top whereas the hanging baffles had four openings $0.30 \mathrm{~m} \times 0.60 \mathrm{~m}(\mathrm{~L} \times \mathrm{H})$ at the bottom. Each digester chamber was fitted with an exhaust gas collection pipe of $0.05 \mathrm{~m}$ diameter and the ABR was connected to the existing sewer system via an inlet pipe at a height of $2.13 \mathrm{~m}$ and an outlet at $2.08 \mathrm{~m}$ relative to the ABR base. The entire ABR was made airtight with manhole covers (Figure 1).

A pre-screen brick-built chamber of dimensions $1 \mathrm{~m} \times 0.5 \mathrm{~m} \times 0.5 \mathrm{~m}$ which contained crisscross steel bars with a spacing of $0.02 \mathrm{~m}$ preceded the inlet to remove solid particles/plastic bags and to avoid choking. 


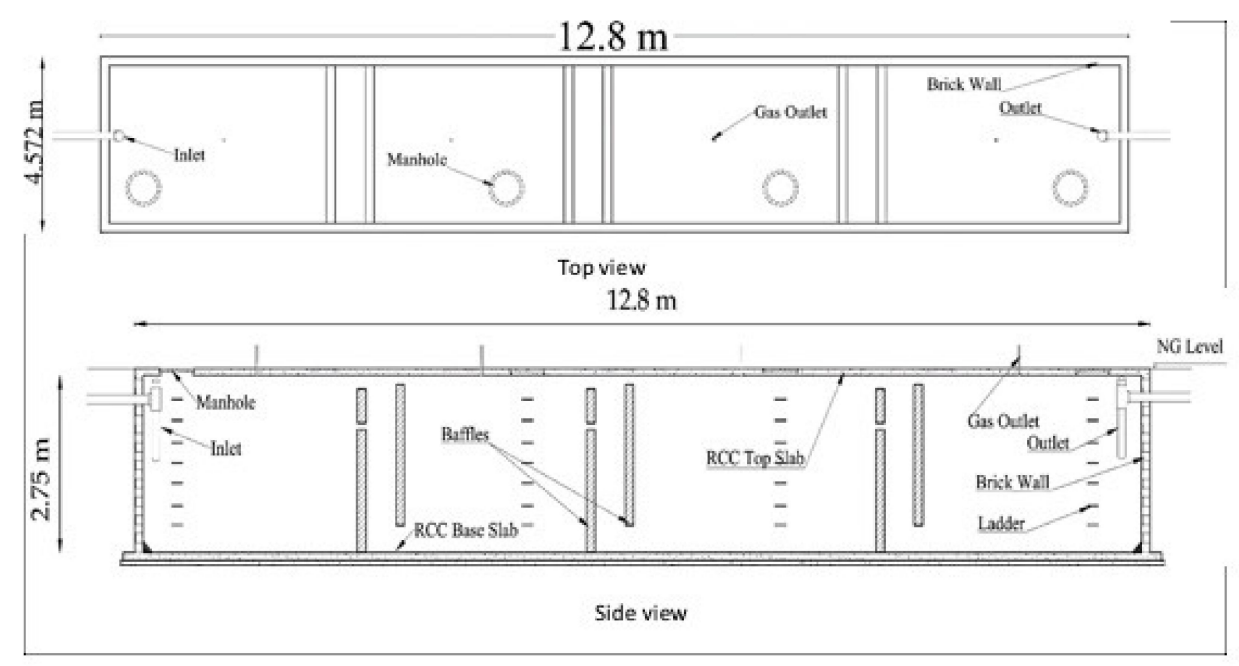

Figure 1. Schematic diagram of the constructed ABR, designed as a primary treatment unit for a housing colony, with features shown, RCC-reinforced cement concrete. A gravel-filled porous columnar filter is also present in the final chamber (not shown).

\subsection{Start-Up and Operation}

Following construction, the ABR was connected to existing sewer lines and started in continuous-flow mode without incubation or sludge seeding in January 2015. Performance of the reactor was studied during the 1st year (2015) after establishment and then again during 2017 following sludge removal (Dec 2016). The reactor was in continuous operation 2015 to 2017, interrupted only transiently for sludge removal by a competent local authority. Neither the volume nor mass of the removed sludge was recorded.

The system was closed with no mixing of outside water (i.e., rainwater) and its flow rate water was calculated by multiplying the cross-sectional area $\left(\mathrm{m}^{2}\right)$ with the observed velocity $(\mathrm{m} / \mathrm{s})$, which varied throughout the year (Table 1$)$.

Table 1. Flow rates, temperature and $\mathrm{pH}$ measured at time of sampling. In both years the HRT was $20 \mathrm{~h}$ and SRT was 100 days.

\begin{tabular}{cccccccccccccc}
\hline Month & Jan & Feb & Mar & Apr & May & Jun & Jul & Aug & Sep & Oct & Nov & Dec \\
\hline $\begin{array}{c}\text { Flow rate } \\
\left(\mathrm{m}^{3} . \mathrm{dL}^{-1}\right)\end{array}$ & 91 & 80 & 113 & 146 & 127 & 133 & 129 & 111 & 119 & 102 & 95 & 80 \\
\hline Temp & 13 & 16 & 21 & 29 & 31 & 34 & 34 & 34 & 28 & 25 & 17 & 14 \\
\hline $\mathrm{pH}$ influent & 8 & 8 & 8 & 8 & 8 & 8.5 & 7 & 8 & 7 & 7.5 & 7 & 7 \\
\hline $\mathrm{pH}$ effluent & 8 & 8 & 8 & 8 & 8 & 8 & 7 & 8 & 7.8 & 7 & 7 & 7 \\
\hline $\begin{array}{c}\text { Flow rate } \\
\left(\mathrm{m}^{3} . \mathrm{dL}-1\right)\end{array}$ & 89 & 83 & 101 & 120 & 143 & 150 & 132 & 121 & 108 & 99 & 91 & 84 \\
\hline Temp & 13 & 16 & 21 & 29 & 31 & 34 & 34 & 34 & 28 & 25 & 17 & 14 \\
\hline $\mathrm{pH}$ influent & 7.8 & 6.8 & 7.8 & 7 & 6.7 & 7 & 7 & 6.5 & 7 & 6.8 & 7 & 7 \\
\hline $\mathrm{pH}$ effluent & 7.7 & 7.2 & 7 & 6 & 7 & 8 & 8 & 8 & 7.6 & 7.7 & 6 & 7 \\
\hline
\end{tabular}

The average hydraulic retention time (HRT) was $\sim 20 \mathrm{~h}$, resulting in a working volume of $92.15 \mathrm{~m}^{3}$ and an organic loading rate (OLR) of $5 \mathrm{~kg} \mathrm{BOD}_{5} / \mathrm{m}^{3}$ per day. The sludge 
volume of the designed $A B R$ was 10\%, with sludge removal intervals of 18-24 months, calculated based on the solid retention time equation of Droste [19]. The temperature varied throughout the year from 13 to $34^{\circ} \mathrm{C}$ and the $\mathrm{pH}$ range was 6-8.0.

\subsection{Sampling and Storage of Wastewater}

The ABR operated at ambient temperature and grab samples were collected at $~ 10$ day intervals in triplicate from the inlet (influent) and outlet (effluent) in $250 \mathrm{~mL}$ sterile bottles from January to December during the years 2015 and 2017. Samples were stored in the ice box and analysis was conducted on the same day in the Applied and Environmental Lab., Quaid-i-Azam University, Islamabad. Standard analysis of COD, $\mathrm{SO}_{4}{ }^{2-}, \mathrm{PO}_{4}{ }^{3}$, TKN and pathogen removal was conducted for each sample.

\subsection{Microbiological Analysis}

Total coliform count (pathogens) was conducted by the most probable number (MPN) method as described in APHA 2005 [20]. Enterobacteriaceae-specific media was used for the MPN determination. Three steps of the process were performed, presumptive test, confirmed test, and completed test, and counts were recorded as MPNL per $100 \mathrm{~mL}$. Culturing media was prepared according to the manufacturer's instructions and pathogen identity confirmed by additional microbiological tests.

\subsection{Physicochemical Analyses}

Sample characterization for chemical oxygen demand (COD), sulfates, phosphate, and total Kjeldahl nitrogen (TKN) used APHA standard methods (Table 2).

Table 2. Physicochemical analysis and method.

\begin{tabular}{cccc}
\hline Characteristics & Units & Method & References \\
\hline COD & $\mathrm{mg} / \mathrm{L}$ & $\begin{array}{c}\text { Closed Reflux } \\
\text { Titrimetric method 5220 }\end{array}$ & {$[20]$} \\
\hline Phosphate & $\mathrm{mg} / \mathrm{L}$ & 4500-P (phosphate) & {$[20]$} \\
\hline Sulfates & $\mathrm{mg} / \mathrm{L}$ & 0375 Barium chrometry & {$[20]$} \\
\hline TKN & $\mathrm{mg} / \mathrm{L}$ & 4500-Norg (organic nitrogen) & {$[20]$} \\
\hline
\end{tabular}

Temperature and $\mathrm{pH}$ were measured using a thermometer and portable $\mathrm{pH}$ meter on-site at the time of sampling. Data analysis (statistical analysis) was carried out using Tukey HSD test (honestly significant difference) with JMP ®provided by SAS (Statistical Analysis System) Institute Inc and presented as histogram plots.

\section{Results}

Performance analysis of the ABR was conducted throughout the initial year of operation, and in the year following the first sludge removal and reactor cleaning, and the data were compared. The operational temperature (seasonal temperature) during this time varied from 14 to $34^{\circ} \mathrm{C}$. The $\mathrm{pH}$ of the influent and effluent wastewater remained within the range 6.0-8.0 during the whole period of sampling, within the recommended range suitable for anaerobic digestion.

\subsection{Comparative Analysis of ABR Efficiency for Two Years}

\subsubsection{Reduction in Chemical Oxygen Demand and Sulfates}

The ABR was fed at an organic loading rate (OLR) of $\sim 19.33 \mathrm{~kg} / \mathrm{d}$. Under these conditions, the COD range of the influent samples was $104-233 \mathrm{mg} / \mathrm{L}$ and the effluent range was $78-215 \mathrm{mg} / \mathrm{L}$ during the first year of operation. The ABR was poorly efficient at reducing the COD during the start-up period from January to May, where it was below $20 \%$. However, for the later months of the year (Sept, Oct and Dec) the COD reduction rose to above $40 \%$, reaching a maximum of $46 \%$ in October and Dec (Figure 2-upper panel). 
The same trend was observed in the second year of analysis, although the numbers were higher overall. The COD reduction was 20-35\% in the first 3-month samples, but again increased to $47 \%$ in July and Aug. Overall, the COD removal rate was more efficient in the second year of analysis, reflecting the time required to establish the removal of COD in the initial year of operation and/or the presence of an existing inoculum in the second year of analysis, which followed sludge removal, consistent with other studies that have shown a lag of up to nine weeks to establishment if seeding is not performed at start-up [21].
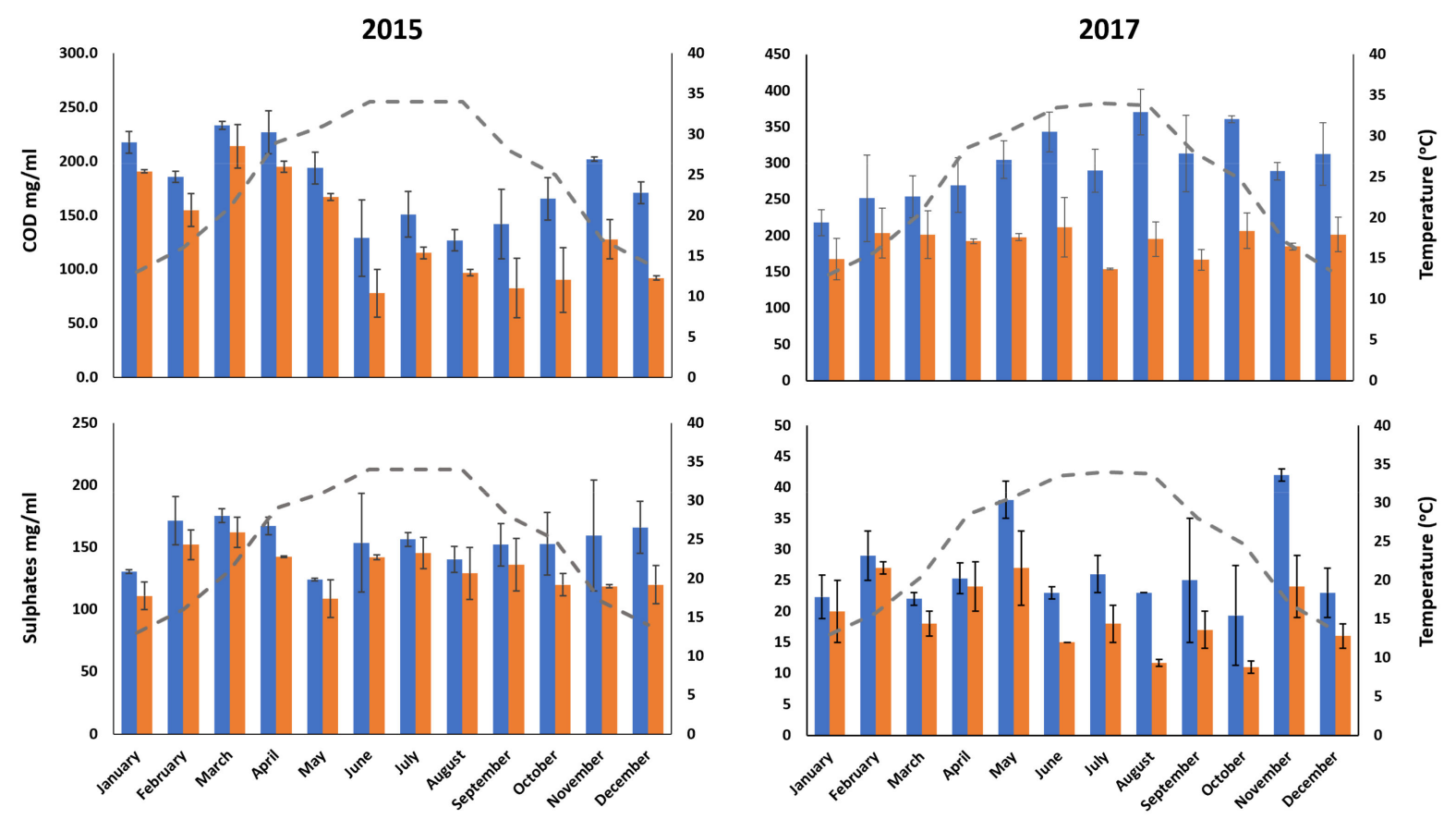

Figure 2. Histogram plot of chemical oxygen demand and sulfate levels during ABR operation in 2015 and 2017. Blue bars-influent samples, orange bars—effluent samples, plotted on the left axes. Dotted line temperature, plotted on the right axes.

As for COD levels, sulfate removal, which ranged from 18 to $174 \mathrm{mg} / \mathrm{L}$ in the influent samples and 12 to $162 \mathrm{mg} / \mathrm{L}$ in the effluent samples, was not consistent throughout the initial year, but increased in the last three months, peaking at $29 \%$ in November. The $A B R$ removed sulfates more efficiently during the second year of observation, which is suggestive of a higher operational stability. The maximum removal was $44 \%$ in August at $34{ }^{\circ} \mathrm{C}$ (Figure 2-lower panel). High concentrations of sulfates may be inhibitory, although concentrations below $500 \mathrm{mg} / \mathrm{L}$ have been reported not to inhibit the anaerobic digestion process [22]. The maximum effluent concentration of sulfates measured here did not range beyond $161 \mathrm{mg} / \mathrm{L}$, well within the inhibitory level. Sulfate reduction results from the activity of sulfate-reducing bacteria, which convert sulfate to sulfide in the anaerobic conditions of the ABR, up to the level of product inhibition [23].

\subsubsection{Reduction in Phosphate and TKN}

The concentration of phosphates during the first operational year ranged from 2 to $11 \mathrm{mg} / \mathrm{L}$ in the influent samples and 1 to $9 \mathrm{mg} / \mathrm{L}$ in the effluent samples. As before, phosphate removal was less than 20\% during the months of March to May but increased significantly to $52 \%$ by September of the same year, although the near temporal figure was variable, with only $24 \%$ measured in one sample in August (Figure 3-upper panel). The concentrations of phosphate measured in the second year of observation were uniformly higher, at 3-12 mg/L and 1-10 mg/L for the influent and effluent samples, respectively. Early year samples recorded up to $35 \%$ removal, reaching a maximum of $58 \%$ in July 
and August. A general decrease in removal rate was observed in the latter half of the year. The growth of biomass is the main mechanism of phosphorus removal, although the requirement for anaerobic microorganisms is generally lower than that of aerobes [24]. In addition, phosphates become complexed with metals such as $\mathrm{Fe}$, and settle with the sludge. Our data agree with other studies, which have reported significant $(80-90 \%)$ phosphorus removal during ABR passage [25]. Further improvements in phosphorus removal may be achievable by modifying the $\mathrm{ABR}$ to increase retention time, and by controlling the flow rate, both of which would enhance the time of contact between the wastewater and biomass. The efficiency observed also suggests that phosphorus concentrations could be tolerated, as the currently recorded effluent levels were well within the range provided by the National Environmental Quality Standards of Pakistan.
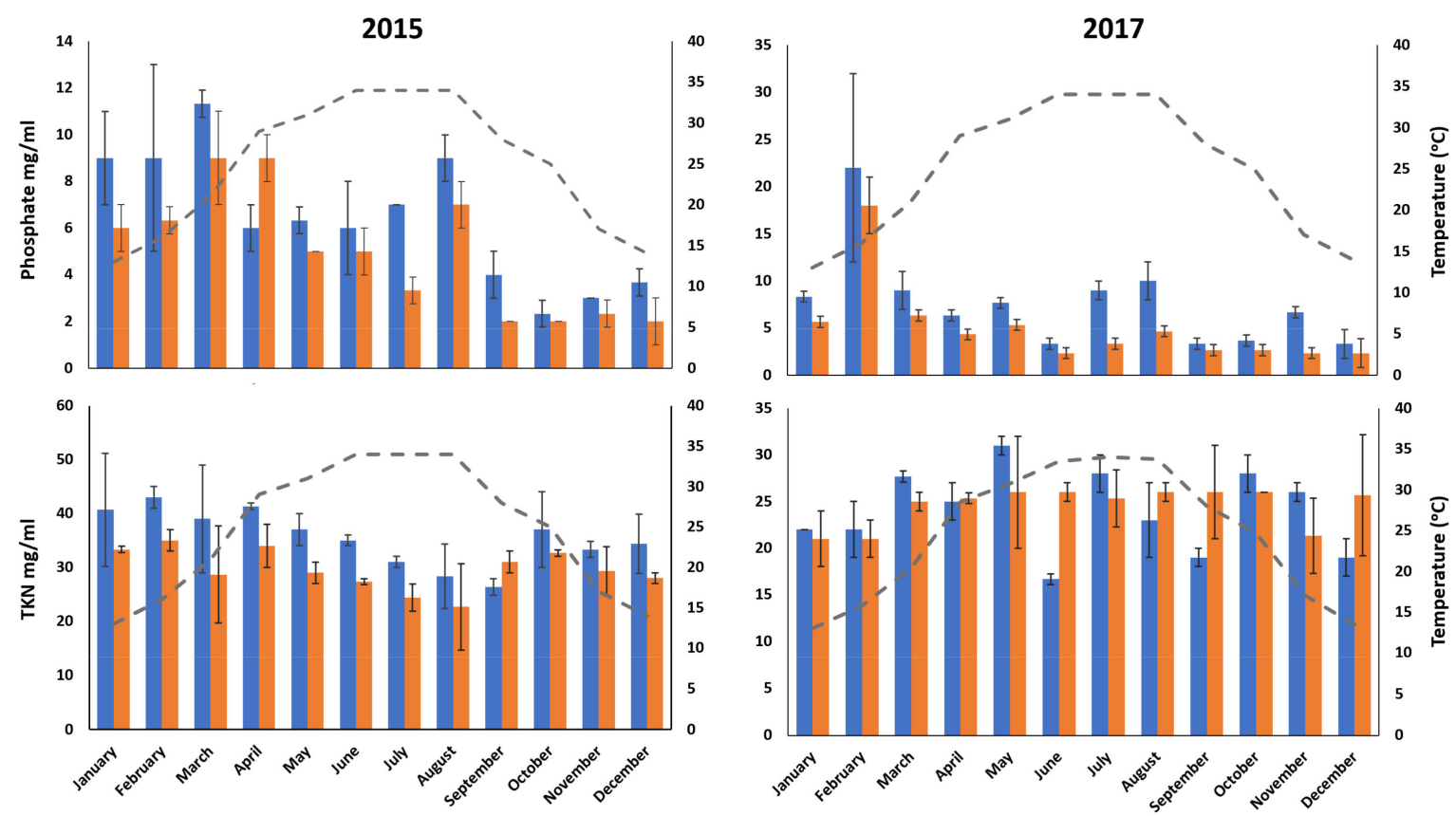

Figure 3. Histogram plot of phosphate and TKN levels during ABR operation in 2015 and 2017. Blue bars- influent samples, orange bars—effluent samples, plotted on the left axes. Dotted line temperature, plotted on the right axes.

Relative to the other parameters measured, a smaller start-up effect was apparent when the TKN levels were compared with an ABR efficiency of up to $20 \%$ for removal in Jan-Apr, increasing to a maximum of only $30 \%$ in the Aug samples, followed by a small decline in the later months (Figure 3-lower panel). Total Kjeldahl nitrogen (TKN), the sum of ammonia and organic nitrogen, was measured as $30-43 \mathrm{mg} / \mathrm{L}$ and $21-35 \mathrm{mg} / \mathrm{L}$ for the influent and effluent samples, respectively, in the first year's samples, and these levels were relatively stable in the second year of observation, with TKN levels of $13-31 \mathrm{mg} / \mathrm{L}$ and $13-40 \mathrm{mg} / \mathrm{L}$ for the influent and effluent samples, respectively. The maximum removal efficiency obtained was also similar, at 31\%. Overall, TKN removal was similar in both years, suggesting the same pattern of microbial metabolism. Some reduction is expected as a result of the consumption of nitrogen by microbial growth in the activated sludge layer, but is countered by the high level of $\mathrm{NH}_{3}$ produced in the $\mathrm{ABR}$ as a component of biogas, leading to a flatter curve overall [7]. The smaller changes are consistent with the observation that the microorganisms involved in nitrogen removal are generally slow growing during anaerobic digestion [26]. 


\subsubsection{Reduction in Pathogen Count}

The pathogen index in the influent wastewater samples, analyzed using the most probable number (MPN) technique and supplemented by microscopy and a range of biochemical tests (Table 3), was $>1100 / 100 \mathrm{~mL}$ per sample for both years.

Table 3. Supplementary tests used Enterobacteriaceae. R—rod; RS—rod; small, R/Y, red/yellow; VP, Voges-Proskauer; TSI, triple sugar iron; MR, methyl red; H2S, hydrogen sulfide production test; K, alkaline (red); A, acid (yellow); NC, no change; $\mathrm{K} / \mathrm{A}$, alkaline slant/acid butt; $\mathrm{A} / \mathrm{NC}$, acid/no color change; - , negative and +, positive.

\begin{tabular}{|c|c|c|c|c|c|c|c|c|c|c|c|c|c|}
\hline Isolate & Morphology & Gram & Citrate & Urease & Catalase & VP & TSI & MR & $\mathrm{H}_{2} \mathrm{~S}$ & Nitrate & Indole & Motility & Identification \\
\hline W1 & RS & - & - & - & + & - & $\begin{array}{l}\mathrm{R} / \mathrm{Y}, \\
\mathrm{H}_{2} \mathrm{~S}\end{array}$ & + & - & + & + & + & Shigella \\
\hline W2 & RS & - & + & - & + & - & $\begin{array}{l}\mathrm{K} / \mathrm{A}, \\
\mathrm{H}_{2} \mathrm{~S}\end{array}$ & + & + & + & - & + & Salmonella \\
\hline W3 & $\mathrm{R}$ & - & + & + & + & - & - & + & + & + & + & + & Proteus spp. \\
\hline W4 & $\mathrm{R}$ & - & - & - & + & - & $\begin{array}{c}- \\
\mathrm{A} / \mathrm{NC}\end{array}$ & + & - & + & + & + & E. coli \\
\hline W5 & $\mathrm{R}$ & - & + & + & + & + & - & & - & + & - & - & Klebsiella spp. \\
\hline W6 & $\mathrm{R}$ & - & + & - & + & + & $\mathrm{K} / \mathrm{A}$ & + & - & + & - & + & $\begin{array}{c}\text { Enterobacter } \\
\text { spp. }\end{array}$ \\
\hline
\end{tabular}

In the start-up year, the pathogen count remained the same in the effluent samples taken in the months of January and February, but began to decline in the March sample, to $460 / 100 \mathrm{~mL}$, and remained similar during April. The pathogens number in the effluent samples fell further, to $93 / 100 \mathrm{~mL}$, in August, and was at a minimum in October, at only $75 / 100 \mathrm{~mL}$, a $>10$-fold reduction overall when compared to the input numbers (Figure 4). The pathogen clearance in the second year of observation was similar, reaching a maximum in Aug and Sept, at 75/100 mL, before a slight rebound in Oct $(93 / 100 \mathrm{~mL}$ ) and Dec $(460 / 100 \mathrm{~mL})$.

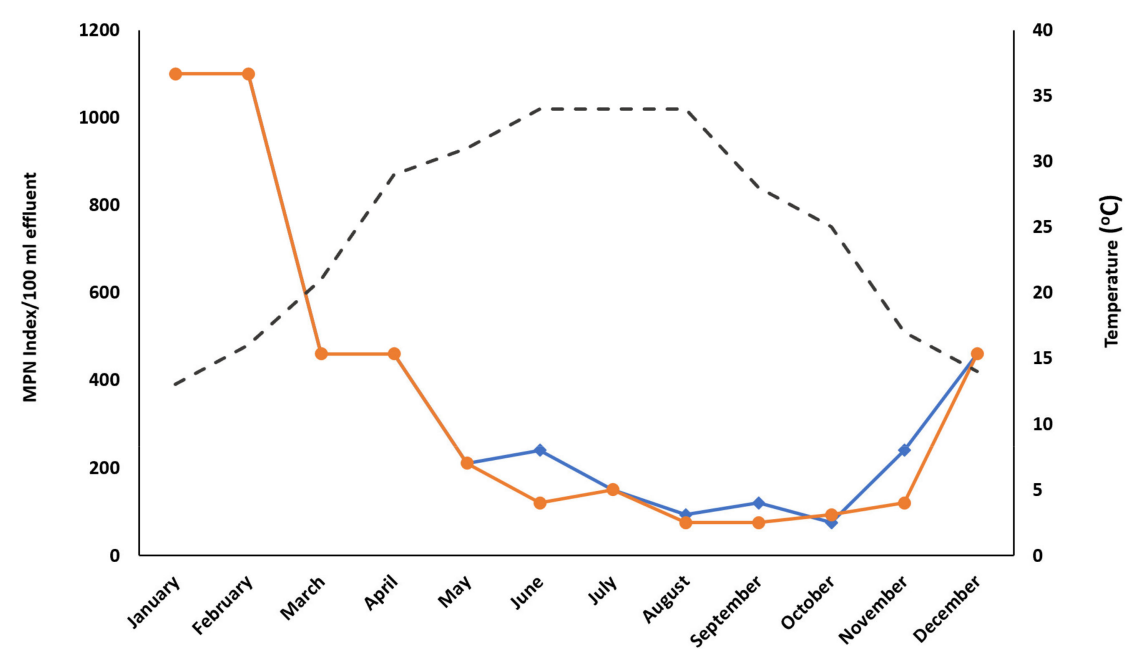

Figure 4. Most probable number values for coliforms in the effluent samples at each month of sample for 2015 ( ) and $2017(\bullet)$. The scale is MPN per $100 \mathrm{~mL}$ of effluent. The ambient temperature at each sample time is as shown in Figures 2 and 3.

\subsubsection{Comparison of Years and Statistical Significance}

The sampling of a live field-scale ABR is subject to many variables that would be fixed in a laboratory-controlled ABR, for example, the following: the time since inception or restart, ambient temperature, flow rate, and the presence of shock loads. Generally, the efficiency of the ABR increased with time and, while this coincided with temperature for 
half of the year, the link with ambient temperature was less marked in samples from later in the year (Table 4. For example, sulfate reduction was higher in both years of analysis, at below the peak annual temperature, consistent with other studies suggesting a temperature impact on the function of sulfate-reducing bacteria in anaerobic digestion [27].

Table 4. Comparative efficiency of ABR over two separate years.

\begin{tabular}{ccccccc}
\hline \multirow{2}{*}{ Parameter } & \multicolumn{3}{c}{ Year 2015 } & \multicolumn{3}{c}{ Year 2017 } \\
\cline { 2 - 7 } & $\begin{array}{c}\text { Max Reduction } \\
\mathbf{( \% )}\end{array}$ & Month & Temp $\left({ }^{\circ} \mathbf{C}\right)$ & $\begin{array}{c}\text { Max Reduction } \\
(\%)\end{array}$ & Month & Temp ( $\mathbf{C})$ \\
\hline COD & 46.0 & Dec. & $14 \pm 2$ & 47.6 & Aug. & $34 \pm 2$ \\
Phosphates & 51.2 & Sept. & $28 \pm 2$ & 58 & July/Aug. & $34 \pm 2$ \\
Sulfates & 28.2 & Dec. & $14 \pm 2$ & 43.5 & Aug. & $34 \pm 2$ \\
TKN & 29.0 & Aug. & $34 \pm 2$ & 31.2 & Sept. & $34 \pm 2$ \\
\hline
\end{tabular}

The peak observed levels of TKN removal were close to those reported by Yulistyorini et. al. [28] and were relatively less dependent on temperature [7]. The values for the second year of observation were generally higher than the first year, reflecting an inoculum effect following sludge removal. Similarly, maximum COD reduction peaked earlier in the second year of observation, even though the same efficiency was achieved at a lower temperature in the first year of sampling. Despite the variability in the figures, a Tukey HSD test of the two-way ANOVA analysis indicated the differences in the influent and effluent samples were significant for each of the parameters measured (Table 5). Importantly, the effluent levels for all the tests were below the national accepted limits, demonstrating effective clean-up in both years of operation.

Table 5. Means ( \pm SE) with $\mathrm{df} 23,48$ at $\alpha=0.05$ for a test of the hypothesis that ABR treat different wastewater parameters Tukey levels not sharing the same letter are significantly different. National Environmental Quality Standards of Pakistan. a, data series 1 and b, data series 2.

\begin{tabular}{|c|c|c|c|c|c|}
\hline \multirow{2}{*}{ Parameters } & \multirow{2}{*}{$\begin{array}{l}\text { NEQs }^{1} \\
(\mathrm{mg} / \mathrm{L})\end{array}$} & Influent (mg/L) & Effluent $(\mathrm{mg} / \mathrm{L})$ & \multicolumn{2}{|c|}{ Tukey HSD } \\
\hline & & \multicolumn{2}{|c|}{ (Mean \pm SE) } & $p$-Value & F. ratio \\
\hline COD & 150 & $(177 \pm 7) \mathrm{a}$ & $(134 \pm 8) b$ & $<0.0001$ & 9.5 \\
\hline $\mathrm{SO}_{4}{ }^{2-}$ & 600 & $(155 \pm 4) \mathrm{a}$ & $(133 \pm 4) b$ & 0.0015 & 2.8 \\
\hline $\mathrm{PO}_{4}{ }^{3-}$ & $<30$ & $(6 \pm 0.6) a$ & $(5 \pm 0.5) b$ & $<0.0001$ & 14.3 \\
\hline TKN & - & $(37 \pm 0.7) \mathrm{a}$ & $(30 \pm 0.7) b$ & $<0.0001$ & 46.8 \\
\hline
\end{tabular}

\section{Discussion}

In this study, an operational ABR unit was assessed over two separate years of operation, as a domestic wastewater treatment facility, and showed good performance stability against seasonal effects and shock loads. The first year of operation was generally less efficient, consistent with the establishment of a non-seeded ABR. The maximum COD removal generally coincided with the hottest parts of the year $\left(28-34{ }^{\circ} \mathrm{C}\right)$, confirming other studies [29], as did the removal of sulfates and phosphates, but the total nitrogen reduction was relatively less affected by temperature. The process stability in this range of temperature is the result of a balance between metabolic activity, on one hand, and the accumulation of toxic by-products, such as ammonia, on the other. Ammonia release by protein hydrolysis increases $\mathrm{pH}$, ultimately inhibiting the process overall, and this is higher under thermophilic rather than mesophilic conditions [30]. Despite the range of temperatures at this latitude, ABR performance was retained, and, while fluctuations in levels were observed, the effluent levels of all the pollutants were below the recommended national levels and were suitable for tertiary treatment at all time points. Our data are consistent with other studies, which found the relative insensitivity of ABR efficiency 
with temperature [31], except when temperature changes were extreme, beyond the range encountered in either year of analysis here [32]. Although temperature was primarily considered as a moderator of ABR efficiency, the lower efficiency observed in some months may have also been related to a decrease in loading rate, as water consumption was 78 $\mathrm{m}^{3} / \mathrm{d}$ in the colder part of the year compared to $132 \mathrm{~m}^{3} / \mathrm{d}$ in the summer. A laboratoryscale study under isothermal conditions could indicate the effect of flow rate, as distinct from temperature, on ABR efficiency, leading to improved implementation of ABRs at the pilot/large scale, with higher efficiency. As noted, the ABR was closed, and rainwater was not part of the inflow. In future, control of the flow rate by the regulated addition of surface water might be considered. Pathogen removal was noted in both the summer and winter seasons, with a more pronounced effect during the summer season, which may reflect the higher temperatures, the higher flow rates or, more probably, the conditions within the ABR. The final columnar porous filter may have also had a positive effect on pathogen removal, as it supports biofilm formation, which competes for resources, even at cooler temperatures $[33,34]$. Our use of a simple ABR design as a primary treatment unit for sustainable and cost-effective water treatment further confirms the data reported elsewhere, which demonstrated ABR effectiveness for denitrification and organic biodegradation [35]. The performance of the ABR could be enhanced further by increasing the number of baffles and capacity, to increase the hydraulic retention time and lessen the effects of shock loads. Other factors, such as scum formation and removal, as studied at the laboratory scale, could also contribute to improved overall performance [36]. An investigation of the microbial populations present in each chamber would allow consideration of supplementation strategies aimed at improving clean-up further.

\section{Conclusions}

ABRs can be applied as cost-effective decentralized wastewater treatment systems, which meet regulatory standards for effluent release and water reuse in Pakistan and elsewhere. The structural advantages of the ABR ensure process stability, resilience against transient shocks, and efficient removal of organic matter and pathogens from wastewater. Although the quality of the treated effluent was marginally better in the summer months, the overall removal efficiency of COD, nitrogen, sulfates and phosphates were $48 \%$, $31 \%, 44 \%$ and $58 \%$, respectively. Other parameters of wastewater were also reduced (Supplementary Materials).

Supplementary Materials: The following are available online at https:/ /www.mdpi.com/article/10

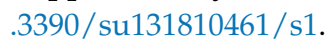

Author Contributions: Conceptualization, S.A. and I.M.J.; methodology, S.A., M.A.; validation, Y.S., S.A. and M.A.; formal analysis, Y.S. and M.A.; investigation, Y.S. and M.A.; resources, S.A.; writing—original draft preparation, Y.S.; writing—review and editing, S.A. and I.M.J.; visualization, Y.S.; supervision, S.A. and I.M.J.; project administration, S.A.; funding acquisition, S.A. All authors have read and agreed to the published version of the manuscript.

Funding: This study was funded by Higher Education Council of Pakistan and USAID under the project "Small Scale Sewage Treatment and Wastewater Reuse System for Pakistan" in collaboration with George Washington University, USA and Quaid-I-Azam University, Islamabad, Pakistan. The ABR system with additional baffles was designed and constructed under supervision of Critical Green ${ }^{\circledR}$ team, under a memorandum of understanding with Quaid-i-Azam University.

Institutional Review Board Statement: Not applicable as not involved humans or animal studies.

Informed Consent Statement: Not applicable, as not involved humans in the study.

Data Availability Statement: Not applicable.

Conflicts of Interest: The authors declare no conflict of interest. 


\section{References}

1. Ptak-Wojciechowska, A.; Januchta-Szostak, A.; Gawlak, A.; Matuszewska, M. The Importance of Water and Climate-Related Aspects in the Quality of Urban Life Assessment. Sustainability 2021, 13. [CrossRef]

2. Hamrang, F.; Shokri, A.; Mahmoudi, S.M.S.; Ehghaghi, B.; Rosen, M.A. Performance Analysis of a New Electricity and Freshwater Production System Based on an Integrated Gasification Combined Cycle and Multi-Effect Desalination. Sustainability $2020,12$. [CrossRef]

3. Jaramillo, M.; Restrepo, I. Wastewater reuse in agriculture: A review about its limitations and benefits. Sustain. Sci. Pract. Policy 2017, 9. [CrossRef]

4. Mahfooz, Y.; Yasar, A.; Guijian, L.; Yousaf, B.; Sohail, M.T.; Khan, S.; Tabinda, A.B.; Rasheed, R.; Mahmood, S.; Khan, M. An assessment of wastewater pollution, treatment efficiency and management in a semi-arid urban area of Pakistan. Desalination Water Treat. 2020, 177, 167-175. [CrossRef]

5. Arooj, M.F.; Haseeb, F.; Butt, A.I.; Irfan-Ul-Hassan, D.M.; Batool, H.; Kibria, S.; Javed, Z.; Nawaz, H.; Asif, S. A sustainable approach to reuse of treated domestic wastewater in construction incorporating admixtures. J. Build. Eng. 2021, 33. [CrossRef]

6. Reynaud, N.; Buckley, C.A. The anaerobic baffled reactor (ABR) treating communal wastewater under mesophilic conditions: A review. Water Sci. Technol. 2016, 73, 463-478. [CrossRef]

7. Hahn, M.J.; Figueroa, L.A. Pilot scale application of anaerobic baffled reactor for biologically enhanced primary treatment of raw municipal wastewater. Water Res. 2015, 87, 494-502. [CrossRef]

8. Langenhoff, A. Treatment of dilute soluble and colloidal wastewater using an anaerobic baffled reactor: Influence of hydraulic retention time. Water Res. 2000, 34, 1307-1317. [CrossRef]

9. Arvin, A.; Peyravi, m.; Jahanshahi, M. Fabrication and Evaluation of anaerobic baffle reactor for leachate treatment of Sari province. J. Environ. Sci. Technol. 2017, 19, 159-171.

10. Musa, M.A.; Idrus, S. Physical and biological treatment technologies of slaughterhouse wastewater: A review. Sustain. Sci. Pract. Policy 2021, 13. [CrossRef]

11. Putra, A.A.; Watari, T.; Maki, S.; Hatamoto, M.; Yamaguchi, T. Anaerobic baffled reactor to treat fishmeal wastewater with high organic content. Environ. Technol. Innov. 2020, 17. [CrossRef]

12. Zhang, C.; Zhang, G.; Wu, F.; Zhou, T. Effect of Elastic Filler on pollutant removal in each compartment of ABR. Sustain. Sci. Pract. Policy 2020, 12. [CrossRef]

13. Sathe, S.M.; Munavalli, G.R. Domestic wastewater treatment by modified bio-rack wetland system. J. Water Process Eng. 2019, 28, 240-249. [CrossRef]

14. Lusk, M.; Toor, G.S.; Obreza, T. Onsite sewage treatment and disposal systems: Bacteria and protozoa. IFAS: Gainesville, FL, USA, 2011.

15. Richards, S.; Paterson, E.; Withers, P.J.A.; Stutter, M. Septic tank discharges as multi-pollutant hotspots in catchments. Sci. Total Environ. 2016, 542, 854-863. [CrossRef]

16. Withers, P.J.A.; Jordan, P.; May, L.; Jarvie, H.P.; Deal, N.E. Do septic tank systems pose a hidden threat to water quality? Front. Ecol. Environ. 2014, 12, 123-130. [CrossRef]

17. Yenji, S.S.; Munavalli, G.R.; Koli, M.M. Field-scale anaerobic baffled reactor for domestic wastewater treatment: Effect of dynamic operating conditions. Water Pract. Technol. 2021, 16, 42-58. [CrossRef]

18. Grand, D.M.D.; Brian, D. ISCO Open Channel Flow Measurement Handbook, 5th ed.; Isco: Geneva, Switzerland, 2001.

19. Droste, R.L.; Gehr, R.L. Theory and Practice of Water and Wastewater Treatment; John Wiley \& Sons: Hoboken, NJ, USA, $2018 ;$ p. 992.

20. American Public Health, A. Standard Methods for the Examination of Water E Wastewater; Ignatius Press: San Francisco, CA, USA, 2005; p. 8.

21. Bodkhe, S.Y. A modified anaerobic baffled reactor for municipal wastewater treatment. J. Environ. Manage. 2009, 90, 2488-2493. [CrossRef]

22. Vossoughi, M.; Shakeri, M.; Alemzadeh, I. Performance of anaerobic baffled reactor treating synthetic wastewater influenced by decreasing COD/SO4 ratios. Chem. Eng. Process. Process Intensif. 2003, 42, 811-816. [CrossRef]

23. Barrera, E.L.; Spanjers, H.; Dewulf, J.; Romero, O.; Rosa, E. The sulfur chain in biogas production from sulfate-rich liquid substrates: A review on dynamic modeling with vinasse as model substrate. J. Chem. Technol. Biotechnol. 2013, 88, 1405-1420. [CrossRef]

24. Feng, H.J.; Hu, L.F.; Shan, D.; Fang, C.R.; Shen, D.S. Effects of temperature and hydraulic residence time (HRT) on treatment of dilute wastewater in a carrier anaerobic baffled reactor. Biomed. Environ. Sci. 2008, 21, 460-466. [CrossRef]

25. Hendrasarie, N.; Trilta, M.N. Removal of nitrogen-phosphorus in food wastewater treatment by the Anaerobic Baffled Reactor (ABR) and Rotating Biological Contactor (RBC). IOP Conf. Ser. Earth Environ. Sci. 2019, 245. [CrossRef]

26. Zhang, N.; Peng, H.; Li, Y.; Yang, W.; Zou, Y.; Duan, H. Ammonia determines transcriptional profile of microorganisms in anaerobic digestion. Braz. J. Microbiol. 2018, 49, 770-776. [CrossRef]

27. Colleran, E.; Pender, S. Mesophilic and thermophilic anaerobic digestion of sulphate-containing wastewaters. Water Sci. Technol. 2002, 45, 231-235. [CrossRef]

28. Yulistyorini, A.; Camargo-Valero, M.; Sukarni, S.; Suryoputro, N.; Mujiyono, M.; Santoso, H.; Tri Rahayu, E. Performance of anaerobic baffled reactor for decentralized wastewater treatment in urban Malang, Indonesia. Processes 2019, 7. [CrossRef] 
29. Ahsan, S.; Rahman, M.A.; Kaneco, S.; Katsumata, H.; Suzuki, T.; Ohta, K. Effect of temperature on wastewater treatment with natural and waste materials. Clean Technol. Environ. Policy 2005, 7, 198-202. [CrossRef]

30. Jiang, Y.; McAdam, E.; Zhang, Y.; Heaven, S.; Banks, C.; Longhurst, P. Ammonia inhibition and toxicity in anaerobic digestion: A critical review. J. Water Process Eng. 2019, 32. [CrossRef]

31. Nachaiyasit, S.; Stuckey, D.C. Microbial response to environmental changes in an Anaerobic Baffled Reactor (ABR). Antonie Van Leeuwenhoek 1995, 67, 111-123. [CrossRef] [PubMed]

32. Barber, W.P.; Stuckey, D.C. The Influence of Start-Up Strategies on the Performance of an Anaerobic Baffled Reactor. Environ. Technol. 1998, 19, 489-501. [CrossRef]

33. Langenbach, K.; Kuschk, P.; Horn, H.; Kastner, M. Modeling of slow sand filtration for disinfection of secondary clarifier effluent. Water Res. 2010, 44, 159-166. [CrossRef] [PubMed]

34. Pfannes, K.R.; Langenbach, K.M.W.; Pilloni, G.; Stuhrmann, T.; Euringer, K.; Lueders, T.; Neu, T.R.; Muller, J.A.; Kastner, M.; Meckenstock, R.U. Selective elimination of bacterial faecal indicators in the Schmutzdecke of slow sand filtration columns. Appl. Microbiol. Biot. 2015, 99, 10323-10332. [CrossRef]

35. Tchobanoglous, G.; Burton, F.L.; Stensel, H.D.; Metcalf \& Eddy. Wastewater Engineering: Treatment and Reuse, 5th ed.; McGraw-Hill Education: New York, NY, USA, 2013.

36. Fujihira, T.; Seo, S.; Yamaguchi, T.; Hatamoto, M.; Tanikawa, D. High-rate anaerobic treatment system for solid/lipid-rich wastewater using anaerobic baffled reactor with scum recovery. Bioresour. Technol. 2018, 263, 145-152. [CrossRef] [PubMed] 